\title{
Adaptive Governance Features from Stakeholder Issues in Lake Limboto Management
}

\author{
Muh. Firyal Akbar ${ }^{1,2}$, Alwi $^{1}$, Nur Indrayati Nur Indar ${ }^{1}$, Muhammad Tang Abdullah ${ }^{1}$ \\ Email: firyalakbar@umgo.ac.id \\ ${ }^{1}$ Hasanuddin University, Jl. Perintis Kemerdekaan KM.10, Tamalanrea, Makassar City \\ 90245, South Sulawesi Province, Indonesia \\ ${ }^{2}$ Universitas Muhammadiyah Gorontalo. J1. H. Mansoer Pateda, Telaga Biru 90222, \\ Gorontalo 96181 Province, Indonesia \\ Received: October 11, 2021 \\ Received in Revised: November 7, 2021 \\ Accepted: November 15, 2021
}

\begin{abstract}
This study aims to examine adaptive governance aspects of the issues from each stakeholder related to the management of Limboto Lake. The implementation of this research uses a qualitative deductive approach. The types of research that will be used are descriptive and explanative types. Sources of data from this research, namely documents and archival records grouped into documentation sources, interviews sourced from people/informants, and direct observation, observation of the role of physical devices grouped in observation sources, and Focus Group Discussions (FGD). The results of this study indicate that efforts to revitalize, rehabilitate and conserve are, of course, not the task of the Government alone but require the participation of the community in them. Conditions of good synergy between the Government, the community and the private sector in efforts to save and manage Lake Limboto are desirable, this is also in line with the achievement of the objectives of adaptive governance in terms of resilience to rapid and unpredictable environmental changes.
\end{abstract}

Keywords: Adaptive Governance, Limboto Lake, Society

\section{Introduction}

Adaptive Governance as a series of interactions between actors, networks, organizations, and institutions that emerge in pursuit of the desired state for a socio-ecological system. In the study of public administration, the concept of Adaptive Governance is part of the development of governance. This concept is used in order to explain the adaptability of governance in the face of external challenges or obstacles. The study of adaptive governance has attracted scholars, especially in responding to climate change and ecology (Folke, 2005; Olsson \& Gunderson, 2006).

This study examines Adaptive Governance specifically on the management of Lake Limboto, Gorontalo Indonesia. The condition of the management of Lake Limboto shows the phenomenon of ineffective management because there is no centralized agency or institution that can fully coordinate the existing agencies and implement programs related to the management of Lake Limboto, thus causing ineffectiveness in the management of Lake Limboto itself. In a further theoretical perspective, this is explained by experts who are concerned with studying the problem of how network governance or more familiarly called network governance, which in this study later became an element of novelty because it had not been disclosed in the previous AG concept.

Regarding environmental problems, Lake Limboto in Gorontalo Province which includes Gorontalo Regency, Gorontalo City, Bone Bolango Regency and North Gorontalo Regency, is currently in a very critical condition due to several problems such as sedimentation, occupation, 
and other damage related to the Limboto Lake ecosystem. One of the most obvious impacts felt by the people of Gorontalo was the overflowing of Lake Limboto which flooded almost most areas, especially those in Gorontalo Regency.

Several other problems outside of the management of Limboto Lake in Gorontalo Province are the unclear communication, coordination and responsibilities of each party responsible for the management of Limboto Lake. According to the formal legal rules, Provincial Regulation Number 1 of 2008 regarding the management of Lake Limboto has been issued as a reference in the management of the lake, but it has not been able to maximize the management of Lake Limboto itself.

Starting from this description, this study looks at the overall problems that occur in the management of Lake Limboto by taking the research locus in Gorontalo Regency as the administratively widest area for Lake Limboto and also as the area most affected by the damage to Lake Limboto. The focus of the research is to look at the adaptive governance of the Gorontalo Regency Government as an institution that is responsible and has the authority to manage Lake Limboto in Gorontalo Regency based on Regional Regulation Number 1 of 2008.

Adaptive governance in this study is seen by the 3 features of AG proposed by Berkes \& Folke (1998), namely motivation/issues; Structure and Network. Furthermore, as explained by Folke et al (2005) that adaptive governance is concerned with socio-ecological conditions related to adaptive governance capabilities which are influenced by the existence of actors, structures, networks, resources, and areas of authority of each level of power.

The adaptive governance approach is used in examining the functions and strategic roles of actors in a concern for the object of multistakeholder study. By focusing on the theory/concept of adaptive governance. As stated by Berkes (2008) which emphasizes the adaptive principle on the ability of the government as the leading sector in reading and consolidating the motivation of stakeholders in an effort to jointly manage an object by building a joint working platform which ultimately forms a collective structure and network as a resource for exchanging resources. each of the actors involved. This study aims to examine adaptive governance aspects of the issues from each stakeholder related to the management of Lake Limboto

\section{Methods}

The implementation of this research uses a qualitative deductive approach. The types of research that will be used are descriptive and explanative types. This type of research was chosen because the researcher wanted to develop in-depth interviews with informants related to the adaptive governance analysis of the Gorontalo Regency Government in the management of Lake Limboto. The location of the research in the research carried out is within the scope of the Province and Gorontalo Regency, although in fact the main locus of this research is Gorontalo Regency, the reason for choosing Gorontalo Regency as the main locus in the management of Lake Limboto. Sources of data, namely documents and archival records are grouped into sources of documentation, interviews are sourced from people/informants, and direct observation, observation of the role of physical devices are grouped into observation sources, and Focus Group Discussion (FGD). In this regard, the informants interviewed in this study were determined by purposive sampling, by looking at the suitability of the prospective informants with the required information. The data analysis technique in this study uses the Spiral model popularized by Creswell (2007). Data Analysis Spiral with the following steps: Data Collection, Data Managing, Reading, Memorizing, Describing, Classifying, and Interpreting, Representing, and Visualizing. 


\section{Results and Discussion}

Stakeholders are very closely related to the trend of issues and interests held by stakeholders in the management of Lake Limboto in Gorontalo Regency because it does not rule out the possibility that in the field there is a substantial conflict of interest in observing and pursuing the lake management process, therefore, the Government as the leading sector needs to responsive and accommodative attitude with the aspirations of the community that reflects the values as a result of the dynamics of their socio-cultural process. In order to facilitate the discussion, the authors use a discussion structure based on the general terms of the governance model consisting of NGOs and the community, the private sector and government organizations.

\section{Society and NGOs}

Several findings that have been obtained in the field indicate that the people around Lake Limboto still rely heavily on livelihoods in the fisheries sector using traditional methods which are not environmentally friendly and can even damage the ecosystem of Lake Limboto. This then becomes a challenge in itself in efforts to save Lake Limboto, which is already very degraded in its environment, its water functions and other ecosystems that exist in Lake Limboto itself. It is the duty of the Gorontalo Regency Government in an effort to provide education and good perceptions for the people around the Lake in order to minimize the current damage to Lake Limboto, even though most of the people do this related to their lives economically.

In addition to economic motivation, cultural motivation is a motivation that is deeply rooted in the community around Lake Limboto. Communities around the Lake Limboto area believe that the existence of Lake Limboto is more than just a source of livelihood and water sources in general. From the secondary data search by the author in the Germadan Limboto document (2014), an explanation was found that historically it can be explained that long ago there was a spring in Limboto Tupalo. One day a boy came down from heaven, very handsome and mighty. His name Jilumoto means an incarnate came to the world. While watching the nymphs bathe in Tupalo, he hid the wings of one of them. It turned out that the wings belonged to the eldest of them. Mbu'I Bungale is her name. Mbu'i Bungale did not find its wings and was eventually abandoned by its brothers. He was then married by Jilumotom and lived together in the cotton hills.

The people of Gorontalo, especially in the coastal area of Lake Limboto, are cultured people. The local culture of the Gorontalo people is generally their ancestral heritage. Namely the "heluma-huyula" system which means openness, mutual help, togetherness, togetherness in building, or discussing any policies taken. In addition to "heluma-huyula" there is also "mototolianga" which means loving each other. But now, this tradition is starting to fade due to the emergence of a new phenomenon, namely "tutuhiya" which means dropping each other, this term is applied to people who cannot see the success of others. As a result, the public's concern for preserving the nature of Lake Limboto is fading.

The function and role of Lake Limboto for people's lives is closely related to the form of culture which is a complex of ideas, ideas, values, norms and other regulations in maintaining human relations with the environment as expressed. In this research, it is known that there is a strong cultural and economic interaction between the people around Lake Limboto and Lake Limboto itself who adheres to the values of the heritage of their ancestors.

Some of the findings obtained by the authors in the field also show that the activities of the people of Lake Limboto are carried out every time in this place, ranging from fishing activities, buying and selling activities of catches, restaurant businesses and other activities that are very 
closely related to the life of the existing community. in Lake Limboto. In some areas around the lake, there are several residential areas that are very close to the shores of the lake. According to some local people, this place was indeed the area of Lake Limboto. used by residents to occupy land so that it becomes property, the funny thing is that the community can get a certificate issued by the relevant agency of the National Land Agency (BPN) in such a process, even though it is clear that the area is still part of protected state land.

This phenomenon has even been recognized by several related parties, such as the Sulawesi River Basin Center (BWS), the Gorontalo Regency Development Planning, Research and Development Agency (BAPPEDA), and the Japesda Community. anticipation of the phenomenon of damage that occurred in Lake Limboto. That the phenomenon of environmental damage is caused by natural factors whose changes cannot be predicted has resulted in extraordinary impacts on the social life of the community and the ecological system of the community itself (Berkes \& Folke 2002). The phenomenon that occurs in Lake Limboto is a big impact from the results related to environmental changes due to natural factors and uncontrolled human activities. The area that should not be occupied by the community has even become a settlement because of the massive sedimentation process, which gives rise to new lands, unfortunately it seems to be used by the people themselves who are less aware of opening up new land as a place to live so that the area of the lake becomes narrow and results in shallowness is happening at the moment. This then becomes a problem when it is feared that this phenomenon will occur continuously in the Lake Limboto area, even though the activities of the people around Lake Limboto can run as usual, but that does not mean that they do not have responsibility and do not participate in maintaining the sustainability of Lake Limboto. its existence is threatened with extinction, but it is precisely the awareness of the people themselves that is needed that Lake Limboto must be saved.

Community activities related to the current condition of Limboto Lake are not only around the main/core area or around the banks of the lake. Those around the upstream area are indirectly related to this. Agricultural and plantation activities by communities in the upstream areas who are very active without following the rules set by the Government and experts to maintain sustainability also seem to be neglected so that the material from these activities, especially those near the watershed that leads to Lake Limboto, plays a very important role. in contributing to sedimentation. From the results of interviews with related parties, in this case the Office of Agriculture and Plantations of Gorontalo Regency, the Department of Environment and Natural Resources of Gorontalo Regency and the Watershed Forum (DAS) revealed the same thing that community activities around the upstream area itself are very massive in contributing to sedimentation caused by agricultural and plantation activities by residents. It was further explained by several informants that the clearing of new land for planting such as corn and several other crops in the slope area has eliminated the function of the forest in minimizing the occurrence of flooding when the rainy season has arrived, and it will automatically have the impact of flooding in the watershed area whose estuary leads to Lake Limboto. This can also be felt by the researchers themselves because they live close to one of the watersheds who have seen firsthand that even though the intensity of the rain is light in other areas, but if it rains with high intensity upstream, the area through which the river flows will feel flooded. because the water from upstream is very large carrying materials such as garbage, big trees and several other materials. This is certainly a phenomenon that community activities regarding motivation/economic interests through increasing the income of communities in the upstream areas with uncontrolled agricultural and plantation activities have played a role in bringing negative impacts to environmental imbalances and leading to the destruction of the Limboto Lake ecosystem itself. 
Regarding the motivation in the adaptive governance dimension, that the magnitude of community participation and interest is very urgent in prioritizing strategic management steps where Folke (2005) describes that there are many desires and interests that are not directly related to what is being sought. but basically it has a fairly massive level of routine and is difficult to contain in influencing the stability of strategy implementation, this is what can be seen as stakeholders who have their own interests and motivations which can then influence in determining the direction of policies regarding the management of Limboto Lake.

Table 1. Motivation and Issues in the Civil Sector

\begin{tabular}{|c|c|c|c|}
\hline Sector & Distracted villages & Issues & Intensity \\
\hline Community & $\begin{array}{l}\text { - Economics } \\
\text { - Customs and } \\
\text { Culture } \\
\text { - Asset ownership } \\
\text { - Social } \\
\end{array}$ & $\begin{array}{l}\text { - Hereditary livelihoods } \\
\text { - Occupational } \\
\text { - Ancestral Heritage } \\
\text { - Continuity of Life }\end{array}$ & $\begin{array}{l}\text { Moderate - High } \\
\text { and implemented } \\
\text { Routinely and } \\
\text { Conditionally }\end{array}$ \\
\hline $\begin{array}{l}\text { NGO's: } \\
\text { - Natural Resource } \\
\text { Management Net } \\
\text { Advocacy } \\
\text { (Japesda) } \\
\text { - Biota Foundation } \\
\text { - Forum DAS Limboto } \\
\text { - Caring Youth } \\
\text { Communication } \\
\text { Forum) 45 Gorontalo } \\
\text { Laskar Lahilote } \\
\text { - GREEN LEAF NGO } \\
\end{array}$ & 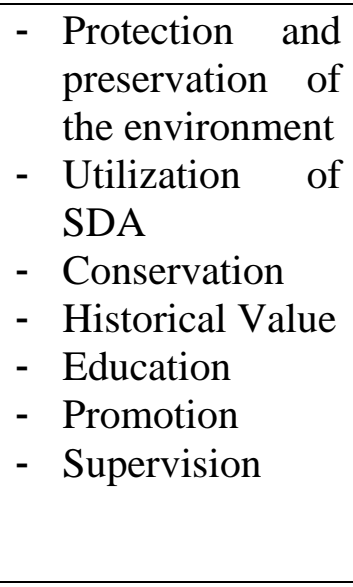 & $\begin{array}{l}\text { - Global Warming } \\
\text { - Environmental damage } \\
\text { - Indigenous and cultural } \\
\text { heritage } \\
\text { - Social conflict } \\
\text { - Threat of Extinction of } \\
\text { Flora and Fauna } \\
\text { - Tourism Potential } \\
\text { - Social behavior }\end{array}$ & $\begin{array}{l}\text { Medium - High } \\
\text { and implemented } \\
\text { Situational and } \\
\text { Conditional }\end{array}$ \\
\hline
\end{tabular}

Source: Results of interpretation of research data after processing

Non-Government Organizations (NGOs) are one of the stakeholders in the management of Limboto Lake which have almost various motivations. With motivation and issues in maintaining and bridging the balance of environmental management activities and community economic resources. The issue of Global Warming has also become a trend in the motivations of several existing NGOs. NGOs are categorized in two ways, namely operational and advocacy, from the operational definition of NGOs as providers of goods and services that are critical to 'clients' in need. Meanwhile, in terms of advocacy, it is NGOs that work as representatives of the community who do not have a voice or access to promote their interests (Hudson, 2002).

One of the things that are consistently carried out in the activities of several NGOs/associations is the effort to maintain the existence of Lake Limboto through educational programs and empowerment programs through training in an effort to preserve the lake. The results of the interview with the Head of Japesda Nurain Lapolo illustrates that Japesda can be said to be a party outside the Government who until now exists to oversee how to protect and protect Lake Limboto from the threat of environmental damage around it which is increasingly massive.

Damage to Lake Limboto according to Japesda, DAS Forum, and Forum 45 that environmental damage such as decreased water function, forest damage in the watershed area, growth of water hyacinth, land occupation from the application of karamba (fishing gear) and community behavior make Lake Limboto as a final disposal site. rubbish). This fact is then in line with research that has been carried out by Hasim, (2011) and Lihawa, (2017) which states that 
environmental degradation in Lake Limboto currently does not occur only in one problem but is very complex which then becomes an accumulation of problems. that must be resolved by the Government and other related parties.

Another thing that is most highlighted by Japesda itself is that the local government still sometimes ignores people's behaviors that are not affirmative to the preservation of the lake so that the negative behavior of the community still occurs and is getting more massive. Furthermore, Japesda said that the damage to Lake Limboto also occurred due to the large number of land clearing for oil palm plantations by the industry and the conversion of forest functions to monoculture crops such as corn, which had an impact on sedimentation as a result of these agricultural and plantation activities.

Regarding the motivation by Japesda as an association that really cares about the existence of Lake Limboto, that what is being done is solely as a form of prevention and preservation related to Lake Limboto itself, besides that the use of natural resources from Lake Limboto is also encouraged as an alternative for the community in an effort to improve welfare. Japesda is also the concern of Japesda and what is the main driving force for them is a form of non-binding supervision with any interests related to things happening in Lake Limboto. According to Nurain Lapolo, the efforts that have been made by Japesda so far are capacity building for the community from upstream to downstream during 2005-2007, then being actively involved and even initiating the issuance of a regional regulation on Lake Limboto No. 1 of 2008, conducting campaigns in the media. social activities related to efforts to preserve the lake, conduct agricultural business training in upstream areas that are affirmative.

Likewise, from the watershed forum, Mr. Irwan Bempah said that what had been done by the DAS Forum as a working partner of the Central, Provincial and Regency Governments was to encourage how the management of existing rivers, especially the 23 watersheds flowing into Lake Limboto, could be maintained. In its existence, according to him, the preservation of the river's ecology is a necessity to maintain the Limboto Lake ecosystem. According to him, conservation action is something that needs to be done immediately because Limboto's condition continues to deteriorate. Authorities can conserve the lake by managing and strengthening the upstream area to reduce sedimentation rates. Several programs that have been carried out by the watershed forum, especially Lake Limboto, are as facilitators in connecting the aspirations of the people around the Limboto watershed area, the watershed forum also carries out studies through research related to the existence of the Limboto watershed as well as providing education to the community around the Limboto watershed area. for how to use the river properly and correctly. In addition, the activities carried out are regular audiences with the Regional Government regarding the current conditions of watershed management in Gorontalo, especially Lake Limboto.

The next NGO that is active in monitoring the existence of Lake Limboto is the Gorontalo Biodiversity Foundation/BIOTA. This foundation is an association founded by several environmentalists, journalists who are concerned with the potential of flora and fauna resources in Lake Limboto, especially in photographing the presence of migratory birds as a unique feature of Lake Limboto.

The existence of NGOs in the management of Lake Limboto is very important in an effort to preserve Lake Limboto while at the same time assisting the Regional Government in managing Lake Limboto. If it is returned to several studies related to NGOs or if in Indonesia we know it as a Non-Governmental Organization (NGO) in relation to the context of governance, then NGOs have a vital role, especially in the context of contemporary state understanding such as Democracy, where NGOs are considered as one of the pillars of Democracy regarding their 
participation. in the country's development process, especially related to public problems, such as environmental damage and forest encroachment, (Yusdiyanto, 2012).

Regarding what has been done by several NGOs in the management of Lake Limboto in Gorontalo, it can be said that these NGOs/NGOs are trying to carry out their functions according to the capabilities and conditions they have, especially related to the motivations and issues they raise in management of Limboto Lake. This is actually in line with what was conveyed by Herren and Izu, (2002), in their paper to formulate a more technical form of the role of NGOs in fighting for global environmental issues. First, NGOs collect, disseminate and analyze information about existing global environmental conditions. Second, NGOs provide input for setting the agenda and the process of developing public policies by local authorities. Third, NGOs actively carry out their functions or operational activities. Fourth, NGOs conduct an assessment of the current global environmental conditions and monitor local authorities' compliance with international environmental agreements that have been agreed upon. Fifth, NGOs advocate the global struggle for environmental justice.

\section{Private Sector Motivation}

In the context of the management of Lake Limboto, from the results of research searches through interview observations and document review, some data and facts on the ground show that the involvement of the private sector is more focused on motivation and economic issues and matters related to the revitalization of Lake Limboto itself. This can be seen from the activities that occur both from the Upstream and Downstream related to Lake Limboto.

Table 2. Motivation and Issues of Private Sector

\begin{tabular}{|c|c|c|c|}
\hline Sector & Motivation & Issues & Intensity \\
\hline $\begin{aligned} & \text { Private: } \\
& \text { - } \text { Restaurant } \\
& \text { Entrepreneur } \\
& \text { - } \text { PT SMS } \\
& \text { - } \text { PT Bumi } \\
& \text { Karsa } \\
& \text { - } \text { PT Tamael } \\
& \text { - } \text { PT Nindya } \\
& \text { Karya }\end{aligned}$ & $\begin{array}{ll}\text { - } & \text { Profit } \\
\text { - } & \text { Employment } \\
\text { - } & \text { Program } \\
& \text { Implementation }\end{array}$ & $\begin{array}{ll}- & \text { Expansion of the } \\
\text { Restaurant area } \\
- & \text { Increase in the } \\
\text { number of visitors } \\
-\quad \text { Local labor } \\
\text { absorption } \\
-\quad \text { Revitalization } \\
\text { Activities } \\
\text { - } \\
\text { Provision of Lake } \\
\text { Fishery Products }\end{array}$ & $\begin{array}{l}\text { - Keep } \\
\text { - Keep } \\
\text { - Keep } \\
\text { - Keep } \\
\text { - Tall } \\
\text { - Tall }\end{array}$ \\
\hline
\end{tabular}

Source: Results of interpretation of research data after processing

In general, the author's observations made in the Limboto Lake area show that the Limboto Lake area is only used by business actors in the restaurant business sector. Almost around the lake area spread over several sub-districts have restaurants that sell several types of fish produced from Lake Limboto such as tilapia, tilapia, eels and several other types of fish. Even now there are restaurant businesses that reach into the lake such as floating restaurants, with the concept of fish products which are then cultivated or caught directly from fishermen, which can be directly enjoyed by visitors who come to the restaurant. One of the business actors interviewed revealed that the existence of Lake Limboto is still their main source of livelihood, and with the development of this business they are increasingly expanding their business area so that more visitors can come.

Other business sector activities apart from restaurant businesses around Lake Limboto are the activities of the Company engaged in the service sector in the Lake Limboto revitalization program. The Revitalization Project which has been started since 2014 under the coordination 
of the Sulawesi River Basin II Center in collaboration with the private sector, namely PT Selaras Mandiri Sejahtera (SMS) which is engaged in construction and as a provider of heavy equipment services. PT. SMS is also a contractor company in the fields of Water Resources (dams and irrigation) and road construction. PT SMS projects are located throughout Indonesia. Lake Limboto is one of the objects that is the work area of PT Selaras Mandiri Sejahtera. As the results of an interview with BWS II Sulawesi Mr. Olden stated that PT SMS has collaborated with BWS II Sulawesi for lake revitalization work in the form of dredging Lake Limboto. From the data obtained by the author, the project work carried out by PT SMS is devoted to maximizing the function of Lake Limboto through the dredging process and sediment control, as well as an effort that functions to control floods covering an area of 2,914 hectares and increase water holding capacity according to BWS II Sulawesi. This project was carried out by PT Selaras Mandiri Sejahtera in collaboration with PT Bumi Karsa with a contract value of $\operatorname{Rp} 229.9$ billion.

Several other companies from the data obtained are also involved in several Government Programs in Revitalizing Lake Limboto, such as PT Tamael, PT Nindya Karya and PT Bumi Karsa. PT Bumi Karsa, for example, is involved in a partnership with BWS II Sulawesi in the revitalization of Lake Limboto. As one of the national construction companies located in the eastern part of Indonesia, since 1969 it has successfully completed various national construction projects such as road construction, dams, irrigation, ports, shopping centers, office buildings, schools, universities, hospitals, factories, and other public facilities. Several types of work that have been carried out by PT Bumi Karsa related to Lake Limboto include dredging work; Lake outlet canal work; Lake embankment works; sediment control building works; bridge construction and maintenance of access roads.

The impression of the private sector in governance is also not entirely positive, some assumptions then assume that the role of the private sector is still not fully maximized because again they only care about profits for their corporations. Especially related to economic activities, sometimes there are many clashes that occur in the field caused by the activities of the private sector in economic motivation that directly collide with the interests of the community (Purna, 2017).

\section{Government Sector Motivation}

Regarding the motivation of the government sector, national action in the form of policies on the management of Limboto Lake is needed to urge the implementation of strategies and action plans to maintain the lake ecosystem. Various efforts to realize the preservation of Lake Limboto in Gorontalo Province, by setting the Vision and Mission as well as programs, strategies, and activities to save the lake can be effective and on target. According to the document contained in the Limboto Lake Rescue Movement (GERMADAN), the vision for the Lake Limboto Rescue is Lake Limboto Lestari in 2025. Raising community awareness and independence in lake management; and Realizing coherence of Lake management policies.

The results of interviews and observations that have been carried out by researchers with several government parties, both at the Provincial and Gorontalo Regency levels through several relevant Regional Apparatus Organizations (OPD), indicate that motivation and issues that are the concern of existing OPDs regarding intervention through programs in Lake Limboto is based on a program that has been designed, structured and implemented according to the needs and main tasks of each of these OPDs.

In general, the OPD's desire to carry out related activities in Limboto Lake is almost the same, namely how to carry out rescues related to the degradation that has occurred until now. Awareness of the importance of restoring the function of Lake Limboto as a support for flora, 
fauna and for the people of Gorontalo itself has become separate to make routine and situational programs, although it is recognized that it is still not optimal in changing the condition of the existing lake.

Activities such as education, empowerment, training, conservation, rehabilitation, and utilization of existing potentials are very important to achieve the goal of saving, managing and using the lake in a sustainable manner. These activities are broken down into several more subprograms, such as the conservation program covering activities for protection, monitoring, and sustainable use. Although from the results of discussions with several informants from each existing OPD that the Limboto Lake problem is a very complex problem and requires special treatment and it will not be effective to directly see the impact, due to several technical factors behind it, including the classic problem, namely the problem of good coordination between the Government and the Government (Central and Regional), as well as the Government and the community.

Table 3. Government Motivation Sector

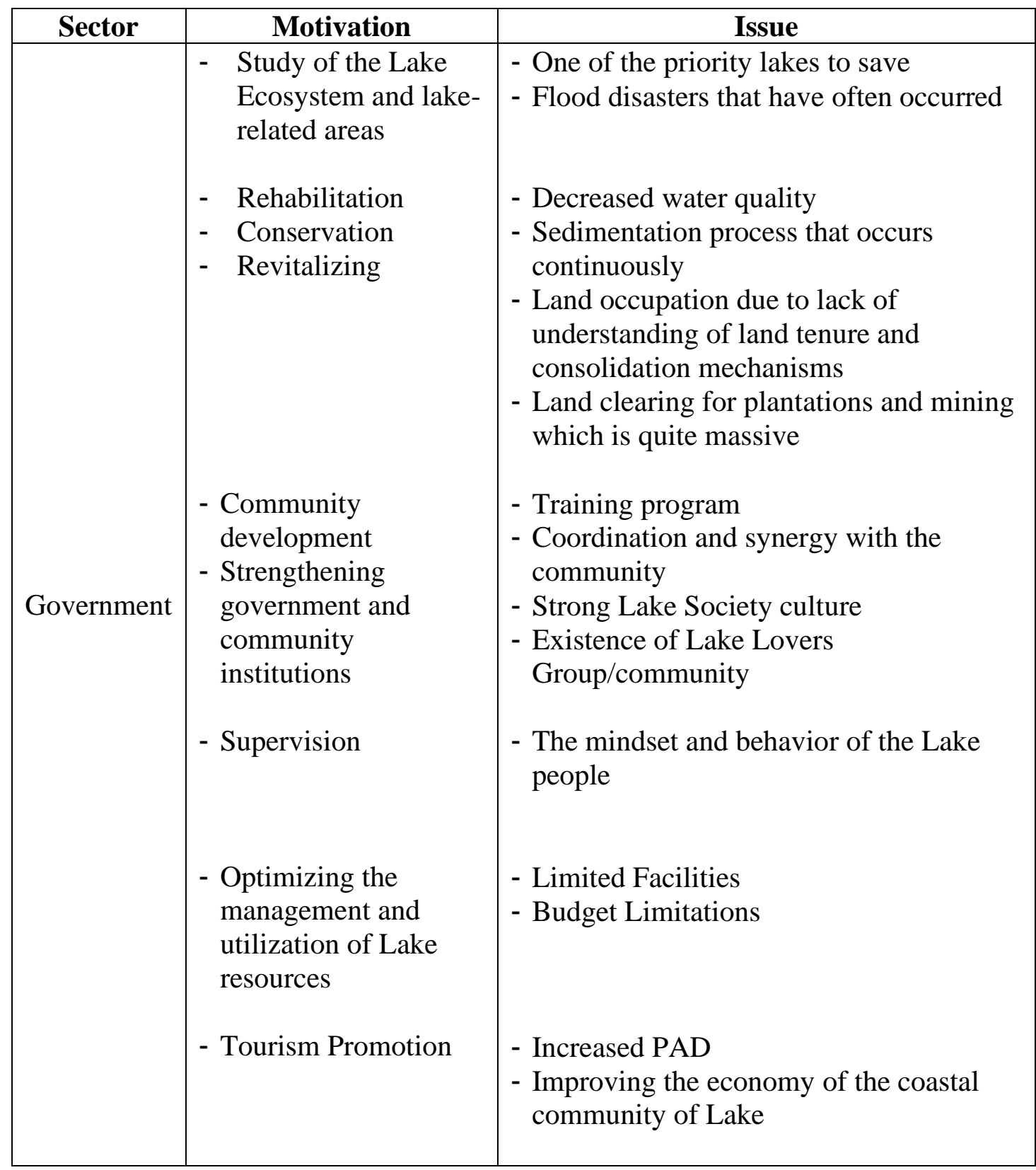




\begin{tabular}{|l|l|l|}
\hline & - Education & - literacy on Lake Limboto \\
\hline
\end{tabular}

Source: Results of interpretation of research data after processing

Efforts through programs have been carried out by OPDs, both vertical institutions in Gorontalo, Gorontalo Provincial Government and Gorontalo Regency Government to revitalize Lake Limboto. Some of the informants acknowledged that these efforts tend to have been carried out frequently, but the results are still not optimal. There is an impression that researchers get that some OPDs related to Lake Limboto tend to only carry out existing programs on a regular basis and the most important thing is that these activities are carried out, but regarding the achievement of results or impacts it still seems that they have not been followed up, so that the program has very little contribution. For example, activities in the field of community empowerment such as training or socialization to the community about the use of fishery products, the use of water hyacinth as handicrafts and organic fertilizers that have been carried out but until now have not been carried out continuously and finally no longer exist.

The position of the public sector as a leader in the Limboto Lake management platform greatly influences how the planning, implementation and monitoring of the lake's rescue. This activity in the perspective of multistakeholders requires synergy and collectivity in its implementation. For the public sector, this collectivity is manifested in a development planning document that contains general dimensions that serve as a reference for all public sector stakeholders in acting.

The previous discussion has shown that there are several formulations of issues and collective targets that Gorontalo Regency has. This means that all agencies within the scope of the Gorontalo Regency government are required to carry out actions on their duties based on this, including the program related to the management of the Limboto Lake rescue. utilization of existing resources in Lake Limboto is a strong enough motivation by the public sector in activities in Lake Limboto.

\section{Conclusion}

The concept of motivation in the context of adaptive governance for the management of Lake Limboto has several motives from each sector, both civil, private and government sectors. The differences in each sector show that each has a role in the management of Lake Limboto until now. An important finding in this study is that the civil sector, especially the community, is still lacking in education about the importance of the existence of a lake that is currently threatened. Efforts to revitalize, rehabilitate and conserve are of course not the task of the Government alone, but require the participation of the community in it. Conditions of good synergy between the Government, the community and the private sector in efforts to save and manage Lake Limboto are desirable, this is also in line with the achievement of the objectives of adaptive governance in terms of resilience to rapid and unpredictable environmental changes.

\section{References}

Berkes, F \& Folke, C. (2003). Navigating social-ecological systems: Building resilience for complexity and change. Cambridge: Cambridge University Press.

Berkes, F \& Folke,C. (1998). Linking Social and Ecological Systems: Management Practices and Social Mechanisms for Building Resilience, Cambridge: Cambridge University Press.

Berkes, F. (2008). Commons in a multi-level world. International journal of the commons, 2(1), 1-6. 
Creswell, John, W. (2007). Qualitative inquiry and research design: Choosing Among Five Approaches (2nd ed.). Inc City: Sage Publications

Folke, C, Carpenter, S., Elmqvist, T., Gunderson, L., Holling, C. S., \& Walker, B. (2002). Resilience and sustainable development: building adaptive capacity in a world of transformations. AMBIO: A journal of the human environment, 31(5), 437-440.

Folke, C, Hahn, T., Olsson, P., \& Norberg, J. (2005). Adaptive governance of social-ecological systems. Annu. Rev. Environ. Resour., 30, 441-473.

Folke, C. (2006). Resilience: the emergence of a perspective for social-ecological systems analyses. Global Environmental Change 16:253-267.

Folke, C. (2007). Social-ecological systems and adaptive governance of the commons. Ecological research, 22(1), 14-15.

Gunderson, L. H., and S. S. Light. (2006). Adaptive management and adaptive governance in the everglade's ecosystem. Policy Sciences 39:323-334. http://dx.doi.org/10.1007/s11077-006-9027-2

Hasim, Sapei A, Budiharsono S, Wardiatno Y. (2011). Analisis Keberlanjutan Pengelolaan Danau Limboto. Jurnal Hidrosfer Indonesia. 6(2).

Herren Gemmill, B., \& Bamidele-Izu, A. (2002). The role of NGOs and civil society in global environmental governance. Global environmental governance: Options and opportunities, 77-100.

Hudson, A. (2002). Advocacy by UK-based development NGOs. Nonprofit and Voluntary Sector Quarterly, 31(3), 402-418.

Lihawa, F., \& Mahmud, M. (2017). Evaluasi Karakteristik Kualitas Air Danau Limboto. Jurnal Pengelolaan Sumberdaya Alam dan Lingkungan (Journal of Natural Resources and Environmental Management), 7(3), 260-266.

Mukhlis, M. (2017). Tata kelola pemerintahan dalam peningkatan kapasitas adaptif/ketahanan kota bandar lampung terhadap dampak perubahan iklim. JIPSI-Jurnal Ilmu Politik dan Komunikasi UNIKOM, 6.

Olsson. P, Gunderson, L. H., Carpenter, S. R., Ryan, P., Lebel, L., Folke, C., \& Holling, C. S. (2006). Shooting the rapids: navigating transitions to adaptive governance of socialecological systems. Ecology and society, 11(1).

Purna, Z. A., \& Ibrahim, M. A. (2017). Strategi mitigasi bencana alam nonstruktural di gunung bawakaraeng dalam perspektif adaptive governance. Jurnal Analisis. 5(1): 25-30

Yusdiyanto, Yusdiyanto. (2015). "Kontruksi Kerjasama LSM Dan Pemerintah Dalam Pembangunan Daerah Perspektif Undnag-Undang Keormasan". Fiat Justisia: Jurnal Ilmu Hukum 6(2). https://doi.org/10.25041/fiatjustisia.v6no2.325 